\title{
Religious Conversion as a Criterion for the Efficiency of Management Strategies in Late Imperial Russia
}

\section{B. Isaeva}

For citation: Isaeva V.B. Religious Conversion as a Criterion for the Efficiency of Management Strategies in Late Imperial Russia. Vestnik of Saint Petersburg University. History, 2019, vol. 64, iss. 4, pp. 1257-1271. https://doi.org/10.21638/11701/spbu02.2019.406 (In Russian)

The article considers forms, methods and factors of religious conversion as the criteria for the efficiency of the management strategies used by the tsarist authorities in late Imperial Russia. Religious conversion is interpreted within the framework of the legal regulation system of religions which was adopted in the 1830-1850s, and its empirical forms are identified. Religious conversion is defined as a transition from the "foreign religions" to Orthodox Christianity and a withdrawal from Orthodox Christianity to the "foreign religions". Two forms of conversion are revealed: orthodoxization and apostasy. In the research the following factors of religious conversion are brought out: a) loyalty to the central government; b) cultural affinity of the ethnic group to the Russians; c) methods of religious conversion. Five types of methods are classified: 1) forced (the elimination of the church organization, repressions of believers and/ or clergy); 2) economic (material incentives); 3) educational (conversion through the native language of the believers, the development of their culture); 4) recruitment (the use of special social and communication strategies); 5) natural (population mixing, inter-ethnic marriages). Based on the reports of the Chief Procurator of the Synod, data from the census of 1897, and other sources the dynamics of religious conversion for 54 years (1860-1914) are analyzed, and its examination by denominations by decades is done. The author concludes that religious conversion indicates certain management strategies - forced integration, gradual acculturation, or preservation of the status quo; their efficiency, existence or absence of the inter-ethnic tensions.

Keywords: religious conversion, Russian Empire, methods of religious conversion, factors of religious conversion, forms of religious conversion, statistics of religious conversion.

Valentina B.Isaeva - $\mathrm{PhD}$ in Sociology, Associate Researcher, The Sociological Institute of the RAS, 25/14, 7-ya Krasnoarmeiskaya ul., St. Petersburg, 190005, Russian Federation; Visiting Researcher, St. Petersburg State University, 7-9, Universitetskaya nab., St. Petersburg, 199034, Russian Federation; vbisaeva@gmail.com

Валентина Борисовна Исаева - канд. соц. наук, ассоциированный научный сотрудник СИ ФНИСЦ РАН, 190005, Санкт-Петербург, 7-я Красноармейская ул., 25/14; приглашенный исследователь, Санкт-Петербургский государственный университет, Российская Федерация, 199034, СанктПетербург, Университетская наб., 7-9; vbisaeva@gmail.com

This article was prepared with the support of grant No. 15-18-00119 of the Russian Science Foundation. Статья подготовлена при поддержке гранта № 15-18-00119 Российского научного фонда.

(c) Санкт-Петербургский государственный университет, 2019 


\title{
Религиозная конверсия как критерий эффективности властных стратегий в позднеимперской России
}

\author{
В. Б. Исаева
}

Для цитирования: Isaeva V. B. Religious Conversion as a Criterion for the Efficiency of Management Strategies in Late Imperial Russia // Вестник Санкт-Петербургского университета. История. 2019. Т. 64. Вып. 4. С. 1257-1271. https://doi.org/10.21638/11701/spbu02.2019.406

В центре внимания настоящей статьи находятся формы, методы и факторы религиозной конверсии как критерии властных стратегий, применяемых в Российской империи в пореформенный период и начале XX в., для управления мультикультурным разнообразием. Дается определение религиозной конверсии в рамках правовой системы регулирования вероисповеданий, которая сложилась в Российской империи в 1830-1850-е гг., выделяются ее эмпирические формы. Религиозная конверсия определяется как переход из иностранных вероисповеданий в православие и выход из православия в иностранные религии. Выявлены две формы конверсии: православизация и апостазия (выход из православия). Процессы религиозной конверсии интерпретируются в контексте национальной политики царских властей. Идентифицируются факторы, обусловливающие религиозную конверсию: а) лояльность центральной власти; б) близость культуры народа к культуре русских; в) методы религиозного обращения. В исследовании классифицированы следующие методы обращения: 1) насильственные (ликвидация церкви, репрессии верующих и/или духовенства); 2) экономические (материальные стимулы); 3) просветительские (обращение с помощью родного языка верующих, развития их культуры); 4) рекрутирование (применение специальных социальных и коммуникативных стратегий); 5) естественные (смешение населения, межэтнические браки). На основе Всеподданнейших отчетов обер-прокурора Синода, данных переписи 1897 и других источников проанализирована динамика религиозной конверсии за 54 года (1860-1914 гг.) по конфессиям по десятилетиям. Делаются выводы о том, что, во-первых, противоречивость национальной политики приводила к вариативности конфессиональной политики и, как следствие, к различным сценариям православизации, реализуемым в разных регионах Российской империи. Во-вторых, идентификация факторов, форм, методов и анализ динамики религиозной конверсии позволяют выявить и оценить интеграционные стратегии, применяемые царскими властями - форсированную интеграцию, постепенную аккультурацию или сохранение статус-кво, степень их эффективности, существования/отсутствия межэтнической напряженности в регионах их применения.

Ключевые слова: религиозная конверсия, Российская империя, методы религиозной конверсии, факторы религиозной конверсии, формы религиозной конверсии, динамика религиозной конверсии.

\section{Introduction}

The article considers processes of religious conversion in late imperial Russia of the post-reform period and at the beginning of the $20^{\text {th }}$ century. Religious conversion is interpreted as a transition to a religion which is not indigenous to the territory of a certain ethnic group ${ }^{1}$. A variety of possible conversion processes is determined by the framework of the state-confessional relations established in the country under review. In the late imperial Russia, such a framework can be characterized as ethnodoxy - a system of

\footnotetext{
${ }^{1}$ Smirnov M. Yu. Sotsiologiia religii: slovar'. St. Petersburg, 2011. P. 128.
} 
ideas which tightly links the ethnic identity of a group with a particular religion and is enshrined at the state level ${ }^{2}$. In the context of ethnodoxy forms, methods and factors of religious conversion can serve as criteria of the management strategies used in the Russian Empire to manage multicultural diversity.

In the post-reform time, the tsarist authorities adopted policies of cultural integration toward the outlying ethnic regions and unification of a multinational empire. Russification and missionary activity of the Russian Orthodox Church were seen as the main instruments of the cultural integration. In this context, cases of mass religious conversions are of empirical interest since they indicate a certain interference by the authorities and the resulting inter-ethnic and religious processes, which were either peaceful and thus reflected the success of the integration policy, or were followed by tensions and conflicts that marked inefficiency, mistakes and violent acts taken against religious and ethnic groups.

In the historiographic literature of the pre-revolutionary, Soviet and post-Soviet periods, an analysis of the certain aspects of the problem of religious conversion processes from the perspective of strategies for managing ethnic and religious diversity has been developed. In pre-revolutionary historiography, the issue was addressed in the works of specialists in state and ecclesiastical law, who focused on the consideration of the legal status of religious denominations ${ }^{3}$, as well as in the documents of the imperial time, examining processes of religious conversion in the context of confessional policies, their geography, causes and conditions of mass religious transitions ${ }^{4}$. It is also necessary to note the works of the Orthodox missionaries, in which the topic of management strategies is not touched directly; nevertheless they contain valuable materials with regard to the processes of religious conversion in ethnic groups of Siberian indigenous people as well as concerning social factors of sectarianism and Old Belief ${ }^{5}$. The historiography of the Soviet period pays attention mainly to criticism of the confessional policy of the imperial period and to the analysis of the phenomenon of religious sectarianism ${ }^{6}$. Modern scholarly literature is represented by works of both domestic and foreign authors ${ }^{7}$ and covers the selected aspects of the study of the processes of religious conversion in the Russian Empire in the frame-

${ }^{2}$ Karpov V., Lisovskaya E., Barry D. Ethnodoxy: how popular ideologies fuse religious and ethnic identities // Journal for the scientific study of religion. 2012. Vol.51, no. 4. P. 644.

3 Reisner M. A. Gosudarstvo i veruiushchaia lichnost': Sbornik statei. St. Petersburg, 1905; Preobrazhenskii I. V. Otechestvennaia tserkov' po statisticheskim dannym s 1840-41 po 1890-91 gg. St. Petersburg, 1897.

${ }^{4}$ Izvlecheniia iz Osobogo zhurnala Kabineta Ministrov 25-go ianvaria, 1-go, 8-go i 15-go fevralia 1905 g. o poriadke vypolneniia punkta 6 Imennogo Vysochaishego Ukaza 12 dekabria 1904 g. // Zhurnal Ministerstva iustitsii. 1905. No. 5; Vsepoddanneishii Otchet Ober-prokurora Sviateishego sinoda po vedomstvu pravoslavnogo ispovedaniia za [1884-1914] god. St. Petersburg, 1886-1916; etc.

5 Veniamin (Smirnov). Ob obrashchenii v khristianstvo mezenskikh samoedov v 1825-1830 godakh. St. Petersburg: Print. E. Fishera, 1851; Zelenin D.K. N.I.Il'minskii i prosveshchenie inorodtsev: (K desiatiletiiu so dnia smerti N.I.Il'minskogo). St. Petersburg: Russkaia shkola, 1902; Bazarianinov V. Osnovnye prichiny i sushchnost' nashego sektantstva. Opyt filosofsko-psikhologicheskogo osveshcheniia sektantstva. Printed copy from "Missionerskogo obozreniia", (1904. No. 1. No. 3). St. Petersburg, 1904.

${ }^{6}$ Bonch-Bruevich V.D. Izbrannye sochineniia in 3 vols. Vol. 1: O religii, religioznom sektantstve i tserkvi. Moscow, 1959; Klibanov A. I. Religioznoe sektantstvo v proshlom i nastoiashchem. Moscow, 1973.

7 Ambartsumov I. V. Nepravoslavnye khristianskie ispovedaniia v sisteme rossiiskoi gosudarstvennosti (konets XIX v. - iiul' 1914): dis. ... kand. ist. nauk. St. Petersburg, 2014; Vert P. Pravoslavie, inoslavie, inoverie: Ocherki po istorii religioznogo raznoobraziia Rossiiskoi imperii. Moscow, 2012. 
work of national and religious policies implemented in relation to various ethnic groups ${ }^{8}$, as well as the history of the certain denominations ${ }^{9}$. Thus the existing historiographical writings contribute to the holistic vision of the legal, national, and confessional contexts in which processes of religious conversion took place in late imperial Russia. However, despite the extensive historiographic literature, there are no generalizing works in which the problem of religious conversion is considered as a distinct phenomenon capable of serving as a criterion and an indicator of strategies used for managing the ethnic and religious diversity in late imperial Russia.

\section{Forms and Factors of Religious Conversion in the Context of the National and Confessional Policy in the Late Imperial Period}

The legal system which regulated the possibilities of changing religious identity in late Imperial Russia emerged in the 1830s-1850s and had existed until 1905 when it was significantly modified. The legislative base of regulation of the confessional system was formed by the "Charter on the Prevention and Punishment of Crimes", which was included in the body of the laws of 1835; the "Code of Criminal and Correctional Penalties" (1845) and the "Charter of the Religious Affairs of Foreign Confessions" (1857). According to this system of regulation of the religious sphere, all confessions were divided into the dominant (the Russian Orthodox Church, hereinafter the ROC), tolerable and intolerable. Irreligious identity was not recognized as possible. Non-Orthodox confessions were officially called "foreign" and were under the jurisdiction of the General Directorate of Religious Affairs of Foreign Confessions, which was incorporated into the Ministry of Home Affairs in 1832 and was renamed the Department of Religious Affairs of Foreign Confessions (hereinafter the DRAFC). The Russian Orthodox Church was administered by the Synod headed by the Chief Procurator.

According to the system of legal regulation, "freedom of religion" was approved, which implied the possibility for each ethnic group of practicing its religion in the territory of the Russian Empire. However, as noted by the Russian historian M.S. Stetskevich, in fact, it was religious toleration since freedom of religion means a free choice of a religion and legislative equality of confessions, which is clearly contrary to the realities of the imperial period ${ }^{10}$. The classification of confessions into dominant, tolerable and intolerable, established at the state level, determined the set of opportunities, privileges and restrictions for the religion of the each category. Orthodoxy as the dominant religion had a higher status among other religions and churches and enjoyed some benefits. It is noteworthy that only the Russian Orthodox Church had the right to missionary activity in relation to representatives of any religion. The only legal restriction was the prohibition of forced conversion. Nevertheless, as will be illustrated below, this regulation was repeatedly

8 Stetskevich M. S. Svoboda sovesti: uchebnoe posobie. St. Petersburg, 2006; Fedorov V.A. Russkaia Pravoslavnaia Tserkov' i gosudarstvo. Sinodal'nyi period (1700-1917). Moscow, 2003; Kappeler A. Rossiia mnogonatsional'naia imperiia. Vozniknovenie. Istoriia. Raspad. Moscow, 2000; Baturin S. P., Baturina T. V. $\mathrm{K}$ voprosu o veroispovednoi politike Rossiiskoi imperii na rubezhe XIX-XX vv. (na primere Sibiri). Vestnik Kemerovskogo gosudarstvennogo universiteta. 2015. Vol. 1, iss. 4. P.7-13.

9 Concerning a comprehensive historiographic review of denominations of the imperial Russia, see Freeze G. L. "Confession in Tsarist Russia: an analytical review of historiography" // Bylye gody. Vol.39. 2016 (2017). P. 261-281.

10 Stetskevich M. S. Svoboda sovesti: uchebnoe posobie. St. Petersburg, 2006. P. 218. 
violated, which was approved at the highest level. In the Charter of the Religious Affairs of Foreign Confessions, the prohibition to impede conversion to Orthodoxy of disciples of foreign faith was emphasized. Violation of the prohibition was subject to criminal punishment - the imprisonment for the period from two months to two years. Conversion of the Orthodox to another faith was not allowed both at the institutional level - in the family (upbringing in another faith), in the process of missionary work; and at the individual level - the individual withdrawal from Orthodoxy. In all cases, that was punished either by imprisonment or by exile, and/or by deprivation of all rights, by homilies with Orthodox priests ${ }^{11}$.

Therefore within the framework of the legal regulation of the religious sphere, which developed in the Russian empire in the first half-middle of the $19^{\text {th }}$ century, religious conversion can be defined either as a transition from "foreign confessions" to the dominant religion, and then it takes the form of orthodoxization, or withdrawal from Orthodoxy to other religions and then it is apostasy. Orthodoxization was the only legitimate form of religious conversion, while any form of apostasy was illegitimate.

The established legal system of regulation of confessions existed until 1917, but in 1905 some alterations were made, albeit not changing its fundamental principles; nevertheless, they were significant in relation to religious conversion. In 1905, a "Decree on Strengthening the Principles of Religious Toleration" was adopted, which relaxed the policy regarding interfaith transitions. The decree regulated the possibility of withdrawal from Orthodoxy to other faiths upon attaining the age of majority. In 1906, criminal penalties for apostasy, for impeding conversion to Orthodoxy, for belonging to a schism, etc. were abolished. Despite those legal changes, the system of state control and regulation of religions, which included the institutions of the Synod and the DRAFC, continued to exist. The gradation of religions into the dominant, tolerable and intolerable, in which the ROC remained the most privileged denomination with the exclusive right to missionary activity among representatives of any religion, was also maintained. Thus, an important consequence of the reforms of 1905-1906 was a legitimization of apostasy, which was the result of the expanding the possibilities of religious choice.

Despite the fact that apostasy was officially legitimized only in 1905, in practice this prohibited form of religious conversion had existed throughout the period under consideration - the post-reform time and the beginning of the $20^{\text {th }}$ century, and in certain cases was mass. This resulted from the fact that the confessional policy of the late imperial period was closely related to the national policy of the tsarist authorities, which indeed determined rights and privileges of each religious group, and political measures which should be adopted within the confessional policy to a particular religious-ethnic group. This is confirmed by the system of privileges of tolerable religions enshrined in the Charter of the DRAFC. M. Reisner, the contemporary of the empire, analyzes the Charter from this point of view and builds a hierarchy of tolerable religions according to the scope of rights and privileges that they had. He concludes that it is built on the national principles: confessions that do not represent entire nations are at a lower level, while peoples with an ancient culture and tradition of statehood occupy a higher position ${ }^{12}$.

Despite its predominant position, the Russian Orthodox Church remained subordinate to the state and limited and guided by its national policy. The synodal reform carried

11 Ibid. P. 208-231.

12 Reisner M. A. Gosudarstvo i veruiushchaia lichnost'. P. 160-162. 
out by Peter I radically changed the position of the Russian Orthodox Church, making it dependent on the state and transforming it into a political instrument of the tsarist authorities. It is in the context of the national policy that the factors that determined the processes of religious conversion, the existing forms of religious transitions and the methods used for their implementation evolved. It must be emphasized that while the fundamentals of the established legal system for regulating confessions remained unchanged throughout the second half of the $19^{\text {th }}$ century and the beginning of the $20^{\text {th }}$ century, the course of the national policy changed in the 1860s, which immediately had consequences in the sphere of inter-ethnic and religious relations. Religious conversion can serve as a bright indicator of these processes.

The Russian historian and sociologist B. N. Mironov distinguishes the basic principles of the national policy in the pre-reform period. The first principle concerned maintaining the status quo of the outlying ethnic regions in the case of their loyalty to the central government - their administrative management and its legal base, culture, language and religion were preserved. Secondly, under the same condition of loyalty, the government provided assistance and cooperated with the non-Russian elites. The third political principle of the tsarist authorities was to endow the non-Russian peoples with rights and privileges as compared to the Russians ${ }^{13}$. As the German historian A. Kappeler notes, the priority was the stability and loyalty of the non-Russian peoples to the Russian monarch; estate and dynastic, rather than ethnic, religious and linguistic principles played an integrative role ${ }^{14}$. Therefore, it can be argued that in the context of national politics in the pre-reform period interethnic and confessional relations in Tsarist Russia were conditioned mainly by the criterion of loyalty/disloyalty of an ethnic and religious group to the central administration.

With the beginning of the Great Reforms in the country there was adopted the unification policy in the form of, first of all, cultural and linguistic integration. The need for the national policy shift was driven by the influence of European nation-states and the need to transform the Russian Empire into a modern state of such a type, the need to modernize it through systematization of management in the legal, administrative and social spheres, making its structure homogeneous and uniting its peoples on the basis of cultural and linguistic principles. Other important motives for the political shift were the national movements and the Polish uprising of 1863. The main tools of cultural and language integration were Russification and conversion to Orthodoxy. However, their application was not consistent and varied depending on the circumstances, which resulted in the contradictions in the national policies of the tsarist authorities in the post-reform period. The unevenness of the assimilatory national policy of the central administration in relation to different ethnic groups was determined by the factors of their loyalty to the central government, which reflects the preservation of the principles of the pre-reform policies. The second significant factor influencing acculturation strategies was cultural affinity of the ethnic group with the Russian culture: the higher the degree of cultural affinity was, the more radical assimilation measures were taken; the less the similarity was, the greater the probability of the status quo policies was ${ }^{15}$. Thus, despite the declared policy of cultural

${ }^{13}$ Mironov B. N. Upravlenie etnicheskim mnogoobraziem Rossiiskoi imperii. St. Petersburg, 2017. P. 143-163, 170-182.

${ }^{14}$ Kappeler A. Rossiia - mnogonatsional'naia imperiia... P. 120.

15 Ibid. P. 203. 
and linguistic integration and unification, the real political measures varied in accordance with the principles of the loyalty to the authorities and cultural affinity.

The above mentioned factors - the assimilation pressure in accordance with the criterion of loyalty/disloyalty to the tsarist administration and cultural affinity of the assimilated ethnic group to the Russian culture - are also essential for religious conversion, namely orthodoxization, used as an integration principle. It was those factors which determined methods of religious conversion used. In the present study, the following methods of religious conversion were identified: forced, economic, educational, recruitment, natural. The inconsistency of the national policy entailed the variability of the confessional policy, and as a result, various orthodoxization scenarios implemented in different regions of the Russian Empire. Based on the analysis of empirical data for 54 years (1860-1914), namely, a consideration of statistical data of the Reports of the Chief Procurator of the Synod, statistics of the 1897 census and other sources, I consider the management strategies implemented by the tsarist authorities through the criterion of religious conversion - its forms, factors, methods and dynamics.

\section{Forced and Economic Methods of Religious Conversion as the Criteria of the Forced Integration Strategy}

The study showed that the highest rates of apostasy were documented in the regions where forced conversion methods in combination with economic ones were used - in the Western provinces and the Privislinsky region for the orthodoxization of the Little Russian Catholics (Ukrainians, Belarusians). Orthodoxization of Catholics was implemented in the context of forced cultural and language integration, the stringency thereof was a reaction to the Polish uprising of 1863 . In response to the disloyalty in the form of the riot, the authorities used a combination of forced (repression against the Catholic clergy) and economic conversion methods ("granting of various civil rights"). Immediately after the uprising of the Poles in 1864, a decree "About the Rules for the Establishment of the Orthodox Fraternities" was issued, which increased the activities of the Russian Orthodox Church in the Western provinces and Poland. It was aimed to create fraternities in order to counter the influence of Catholicism on the peasant peoples - Belarusians, Lithuanians and Ukrainians, and to weaken the position of the Catholic clergy as a support of the Polish elites. Repressive measures against the Catholic clergy were taken: church lands were confiscated, clergymen were defrocked, monasteries were closed. Forced conversion was focused mainly on people with cultural affinity with Russians - Belarusians and Ukrainians.

Graph 1 characterizes the dynamics of orthodoxization of Catholics over the years 1860-1914. High rates of orthodoxization in 1870-1880 were conditioned by the elimination of the Greek Catholic Church organization: in 1875, in the context of the stringent acculturation measures 250,007 Uniates were converted to Orthodoxy by force. The total number of Catholics (Greek and Roman Catholics) who were converted to Orthodoxy during the decade of 1870-1879 comprised 268,344 people ${ }^{16}$, and it was the highest rate compared to other decades for the whole period under consideration.

${ }^{16}$ Preobrazhenskii I. V. Otechestvennaia tserkov' po statisticheskim dannym s 1840-41 po 1890-91 gg. P. 46. 


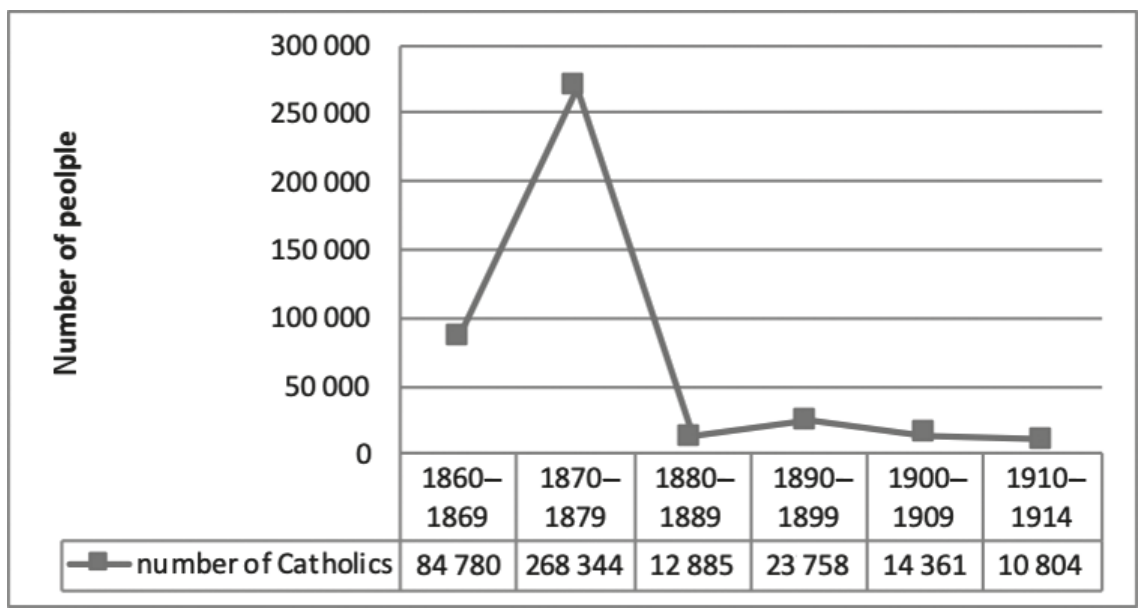

Graph 1. The dynamics of orthodoxization of Catholics (Greek and Roman Catholics) in the Russian Empire in 1860-1914 ${ }^{17}$

It was in the Privislinsky region and the Western provinces, where forced methods of religious conversion had been applied, that the highest rates of apostasy from Orthodoxy to Catholicism in 1905-1914 were documented, including apostasy on the part of the former Uniates. Only in the first three years (1905-1907), after the state legitimization of apostasy 170,936 people reverted to Catholicism in the Western provinces. The total number of the cases of apostasy between 1905-1914 for Catholics was 189,332, while the total indicator of orthodoxization between 1860-1914 amounted to 414,932 people. Therefore, in general, the dynamics of orthodoxization exceeded the dynamics of apostasy, but it is important to note two limitations. First, the official statistics of apostasy are available from 1905 when this form of religious conversion became legitimate. Secondly, in the illegitimate form it existed before 1905, which is noted in the reports of the Chief Procurator of the Synod, but because of its illegitimacy it cannot be precisely assessed. In fact, it was a situation of a dual faith, when formally belonging to the ROC, citizens professed their former religion. Such a hybrid form of identity can be designated as a nominal dual faith.

In sum, in the Privislinsky region and the Western provinces, the disloyalty of the local ethnic groups to the central administration (Polish uprising) and Catholicism regarded as the influence of "Polonism"; the cultural similarity between the Little Russians and the Great Russians resulted in the use of the most stringent methods of religious conversion - forced in combination with economic ones, which resulted in the coexistence of a legitimate form of religious conversion, orthodoxization, with an illegitimate one, apostasy, in the period before 1905, and high rates of apostasy after 1905.

The economic methods of religious conversion included the use of material incentives to motivate the transition to another religion. The economic methods of conversion were used in the Baltics for orthodoxization of Lithuanian and Estonian Protestants in the context of the struggle against the influence of the German Baltic elites. Mass conversions of Latvian and Estonian peasants to Orthodoxy took place in the 1840s and were conditioned on the one hand by the agrarian crisis, and on the other - by the information spread

${ }^{17}$ Compiled from: Preobrazhenskii I. V. Otechestvennaia tserkov'... 
by Orthodox missionaries that peasants who converted to Orthodox Christianity would be able to get economic benefits from the tsarist government, including lands. However, already in the 1850s, many newly converted peasants began to petition for returning to Lutheranism since they did not receive the expected material benefits, and as the official withdrawal from Orthodoxy was not possible, a large group of those who had abandoned Orthodoxy emerged in the Baltics. Ambartsumov, referring to the Journals of the Minister Committee on the execution of the decree of December 12, 1904, notes that in 1905 in the Baltic provinces there were about 30 thousand apostates ${ }^{18}$. It should be pointed out that the Russian government really attempted to free the newly baptized Orthodox Christians from paying taxes, but this intention was resisted by the local elites, with whom the tsarist administration traditionally cooperated, therefore the relevant laws were not adopted ${ }^{19}$.

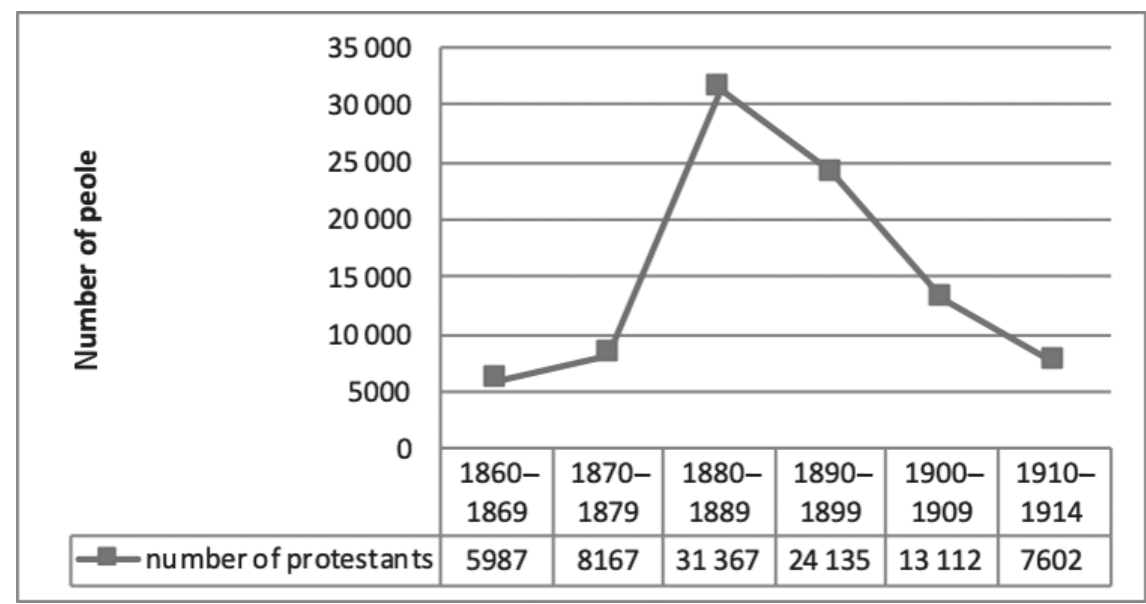

Graph 2. Orthodoxization of Protestants in the Russian Empire in 1860-1914 ${ }^{20}$

Graph 2 shows that the highest rates of orthodoxization of Protestants were documented in the 1880s and 1890s. Most of the converts were Baltic Lutherans. In 1881, Alexander III ascended the throne, who for the first time did not confirm the privileges of the Baltic Germans and began to pursue the policy of systematic unification in the form of Russification in the Baltic provinces and countering the influence of the German Lutheran elite on the peasant population ${ }^{21}$. On May 14, 1886, the emperor signed a law prohibiting the collection of taxes, including land taxes, in favor of the Lutheran church from the persons listed in Orthodox parish registers. As the German historian Gerhard Simon remarks, this law was perceived by contemporaries, especially by the Baltic elite, as "a fee or a reward for the conversion to Orthodoxy" 22 , which is consistent with the strategy of

18 Ambartsumov I. V. Nepravoslavnye khristianskie ispovedaniia v sisteme rossiiskoi gosudarstvennosti...; Vert P. Pravoslavie, inoslavie, inoverie... P. 213.

19 Kappeler A. Rossiia - mnogonatsional'naia imperiia... P. 192-193; Simon G. Pastorskie protsessy // Novoe voennoe obozrenie. 05.06. 2002. URL: http://nvo.ng.ru/history/2002-06-05/11_process.html (accessed: 15.01.2019).

20 Compiled from: Preobrazhenskii I. V. Otechestvennaia tserkov'...; Vsepoddanneishii Otchet Oberprokurora Sviateishego sinoda...

${ }^{21}$ Kappeler A. Rossiia - mnogonatsional'naia imperiia... P. 191.

22 Simon G. Pastorskie protsessy. 
economic methods of religious conversion which the government had tried to apply in the 1840s. The total number of Protestants who converted to Orthodoxy in 1860-1914 was 90,370 people. It was among the Lutherans of the Baltic States in the three Baltic provinces that the highest rates of apostasy after 1905 were observed, and in the years 1905-1914 involved 17,776 people p $^{23}$.

\section{Educational and Natural Methods of Religious Conversion as the Criteria for Gradual Acculturation Strategies}

Educational methods of religious conversion, the reformation system of missionary methods of N. I. Il'minskii, were used for Christianization of Siberians and peoples of the Far East; for prevention the Turkish-Tatar and Finno-Ugric peoples of the Volga-Ural region, who had already converted to Orthodoxy, from apostasy. There were also attempts to use the Il'minskii system in Central Asia. The main idea of the orientalist Il'minskii was a revolutionary one since it supposed the separation of confessional identity from ethnicity, namely, Orthodoxy from Russianness. Linguistic assimilation was assumed only in the long term perspective, while the immediate aim of the Il'minskii system was orthodoxization.

As part of Il'minskii's missionary activity, Cyrillic alphabets were developed for a number of unwritten languages of the indigenous peoples of the Russian Empire. Indigenous languages were used for the translation of the Orthodox canonic literature and religious services. Educational methods of conversion proved to be effective in relation to the pagan tribes of Siberia and the Far East, which is confirmed by the high rates of orthodoxization throughout the period under review and the low rates of apostasy. Graph 3 illustrates that in the years 1860-1914, the total rate of orthodoxization of the pagans was 166,842 people, while the indicator of apostasy in the years 1907-1914 was 890 people. In the 1890s, the growth of orthodoxization slowed down since, according to the census of 1897, the proportion of the Orthodox Christians among the Northern tribes was $64.4 \%$ of the population ${ }^{24}$.

Orthodox missionaries who worked in Siberia noted a syncretism of the beliefs of indigenous peoples, which was formed as a result of Christianization. In their daily life, practices and ideas of the Christian cult and Paganism were mixed ${ }^{25}$. This form of religiosity can be described as a real dual faith, in contrast to the nominal dual faith that existed in the Western provinces of the empire.

A student of Il'minskii N. P. Ostroumov tried to use the Il'minskii system in Central Asia, but to no avail, since the missionary activities of the Orthodox Church were prohibited in the context of a policy of non-intervention in order to maintain social and political stability in the region. Thus, the absence of any form of religious conversion indicates the strategy of preserving the status quo on the part of the authorities.

${ }^{23}$ Vsepoddanneishii Otchet Ober-prokurora Sviateishego sinoda...

24 Obshchii svod po Imperii rezul'tatov razrabotki, dannykh pervoi vseobshchei perepisi naseleniia, proizvedennoi 28 ianvaria 1897 goda: in 2 vols. Vol.2. St. Petersburg, 1905. P. 126-127.

${ }^{25}$ Chumakova T. Pravoslavnye sviashchenniki - issledovateli religii narodov Rossii // Gosudarstvo, religiia, tserkov'v Rossii i za rubezhom. 2018. Vol. 1. P. 12-32. 


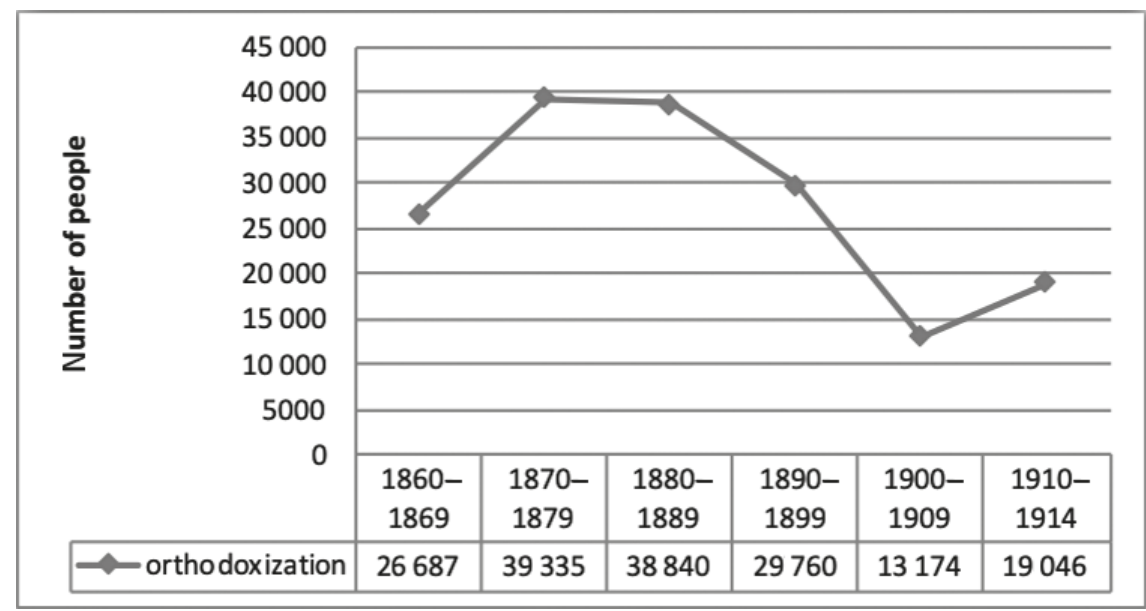

Graph 3. The dynamics of the orthodoxization of the pagans in the Russian Empire in $1860-1914^{26}$

Natural methods of religious conversion imply an intermingling of population, including through inter-ethnic marriages. Unlike in Europe, marriage in the Russian Empire was considered to be a religious institution, the order of which was established by church law. Although mixed interfaith marriages were regulated not only by confessional law, but also by civil law since it was necessary to establish a procedure for regulating a religious affiliation of both spouses and their future children taking into account a confessional affiliation of each party. Mixed marriages between the Orthodox and representatives of other Christian confessions became very common in the $19^{\text {th }}$ century, and their geography covered mainly the national outskirts of the empire. Mixed marriages were legitimized at the state level in 1721 by Peter the First, who pursued a liberal policy towards foreigners and reformed the legal regulation of the religious sphere in accordance with this trend. According to the Petrine norms, non-Orthodox Christians could marry Orthodox Christians preserving their faith and not forcing the spouse to change his or her religion. It was a must to bring up children in the Orthodox faith. These obligations, according to Article 67 of the Civil Laws, had to be documented by non-Orthodox Christians in the signed testimony before the wedding. The wedding ceremony itself was conducted by an Orthodox parish priest, the marriage data were registered in a parish register "on the newly-married", which was an official document for acts of civil status ${ }^{27}$.

An American historian, a specialist in Russian history Pol Vert remarks that the problem of legal regulation of mixed marriages was of political importance since it was associated with the most difficult for the political management peripheral regions - the Baltic States and the Western provinces. In theory, the marriage legislation was considered by the authorities to be an instrument of orthodoxization, and, therefore, integration of the population of the outlying ethnic regions. However, in practice, the difficulties associated with the rigidity of the position of the Catholic Church on interfaith marriages, as well as

${ }^{26}$ Compiled from: Preobrazhenskii I. V. Otechestvennaia tserkov'...; Vsepoddanneishii Otchet Oberprokurora Sviateishego sinoda...

${ }^{27}$ Ambartsumov I. V. Nepravoslavnye khristianskie ispovedaniia v sisteme rossiiskoi gosudarstvennosti... P. 196-201. 
the limited capabilities of the tsarist authorities in the legal regulation of such marriages, led to the conclusion that institution of marriage could hardly be used as a targeted tool of conversion to Orthodoxy, and therefore integration ${ }^{28}$.

Thus, it must be concluded that the dynamics of religious conversion in the context of natural conversion methods requires a special in-depth study, analysis of parish registers of the regions where mixed marriages were common. Within the present research, it can be assumed that natural conversion methods did not result in mass religious transitions because, firstly, raising children in the Orthodox faith is not a religious conversion, as there is no interfaith transition and the factor of religious socialization works. Secondly, the analysis of the dynamics of orthodoxization and apostasy according to the reports of the Chief Procurator of the Synod and other sources revealed the cases of mass conversion during the period under review (1860-1914) and showed that mass religious transitions were conditioned by the use of other methods of religious conversion - forced, economic, educational and recruitment.

\section{Religious Recruitment Methods as the Criterion for the Strategy of Counteraction to Rational Sectarianism}

The use of recruitment methods for religious conversion involves the application of special social and communication strategies aimed at shaping of interest in the activities and world view of the religious group for a potential adherent and the motivation of affiliation to the community. A specific feature of recruitment is the more individual character of interaction with potential disciples: orientation to the social and spatial characteristics of the environment in which representatives of a religious group and a potential follower interact, attributes of the neophyte, and the choice of means of communication ${ }^{29}$. The use of recruitment methods was in demand at the end of the $19^{\text {th }}$ century because of the rationalistic sectarianism - the new phenomenon which appeared and became widely spread in the post-reform time. Recruitment methods were used both by the sects and by the Orthodox Church.

The term "rationalistic sects" denoted the Christian denominations of the sectarian type, which preached the ideas of freedom and universal equality and minimized the rituals of a religious cult. The rationalistic sects included both imported religions, and among them Stundism, Baptism, Mennonitism, etc., and those emerged in Russia, such as the Dukhobor religious sect, Malakanism, Tolstoyism, the Pashkovtsy sect, etc. Their religious teachings did not acknowledge the clerical hierarchy, the sacrament of confession, monasticism, worship of relics, saints and icons; some sects (for example, the Dukhobors) did not acknowledge secular authorities ${ }^{30}$. Thus, because of the particular features of their world view, rationalistic sects were dangerous to both the state and the Orthodox Church.

28 Vert P. Pravoslavie, inoslavie, inoverie... P. 143-145.

29 For a detailed review of recruitment methods, see: Snow D. A., Zurcher L.A., Ecland-Olson S. Social networks and social movements: a microstructural approach to differential recruitment // American Sociological Review. 1980. Vol.45, iss. 5. P.787-801; about recruitment model as a conceptual model of religious conversion see: Isaeva V.B. Sotsiologicheskie issledovaniia religioznoi konversii v zarubezhnoi nauchnoi traditsii: klassicheskie kontseptual'nye modeli // Nauchnoe obozrenie. Seriia 2. Gumanitarnye nauki. 2013. Vol. 6. P. 28-36.

30 Fedorov V. A. Russkaia Pravoslavnaia Tserkov' i gosudarstvo. P. 228-229. 
Between 1887 and 1917, the Russian Orthodox Church held five missionary congresses, and one of the central issues was the spread of sectarianism. To counteract sects, it was decided to use the recruitment conversion methods similar to the ones used by the sectarians themselves. In 1908, the Synod adopted new rules for the missionary activity of the Russian Orthodox Church in the Russian Empire. The rules focused on various forms of individual influence on those who left Orthodoxy: "exhortatory talks", organization of missionary schools and church choirs. Another task was to educate lay Orthodox people as preachers, i.e. according to the Baptist principle of "universal priesthood", and therefore the national missionary courses were organized. Innovative for patriarchal Russia was the decision to involve women to counteract sectarianism: it was proposed to introduce into the programs of diocesan women's schools subjects on schism and sectarianism and to open a theological institute for women. Thus, women in their daily life through communication and interaction with others could participate in the prevention of apostasy from Orthodoxy and the recruitment of those who had already left Orthodox Christianity. Besides, in the long term perspective they could carry out educational functions. The Russian Orthodox Church also adopted some other ideas used by sectarians, namely the propaganda of a strong work ethic, sobriety, and the organization of sobriety fraternities ${ }^{31}$.

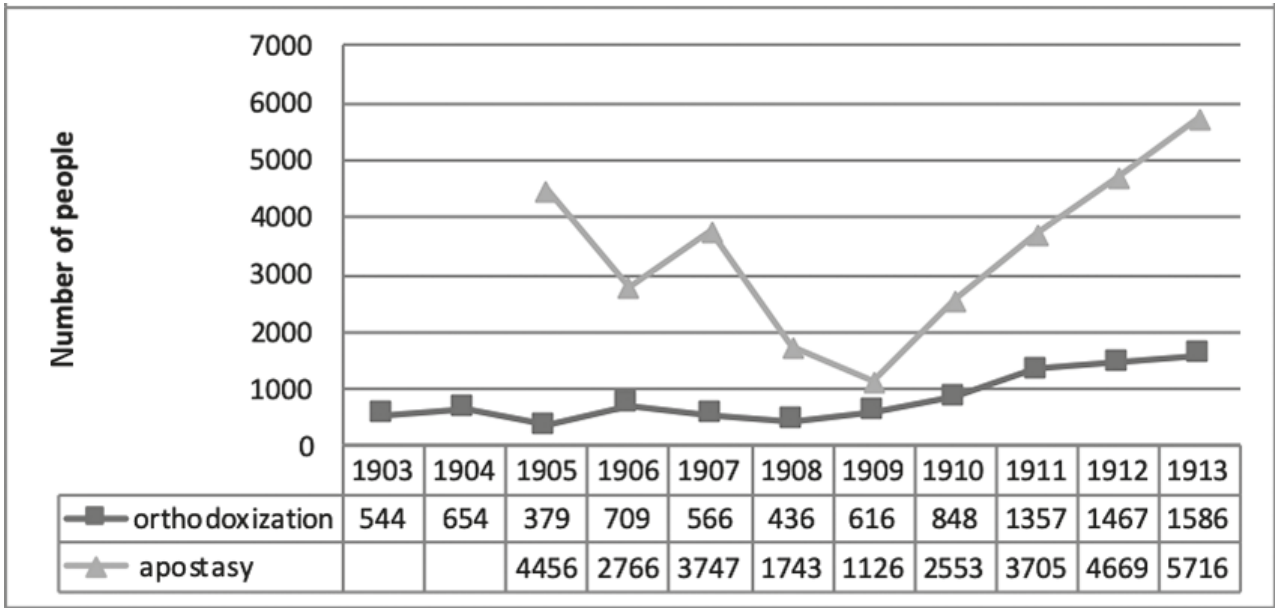

Graph 4. The dynamics of religious conversion of sectarians in 1903-1914 ${ }^{32}$

Graph 4 demonstrates the dynamics of orthodoxization of the sectarians from 1903 (when there appeared a separate counting column for orthodoxization of the sectarians in the eparchies in the reports of the Chief Procurator of the Synod) to 1914 compared with the dynamics of apostasy from 1905 to 1914 . Obviously, despite the anti-sect campaign of the Russian Orthodox Church, general socio-economic conditions in the country, the liberalization of legislation regulating interfaith transitions from Orthodoxy to other Christian religions, and the intensive activities of the religious groups themselves qualified as sectarian contributed to the growth of such transitions, which is reflected by

${ }^{31}$ Baturin S. P., Baturina T. V. K voprosu o veroispovednoi politike... P. 11-12.

32 Compiled from: Vsepoddanneishii Otchet Ober-prokurora Sviateishego sinoda... AmbartsumovI. V. Nepravoslavnye khristianskie ispovedaniia $\mathrm{v}$ sisteme rossiiskoi gosudarstvennosti... 
the dynamics of apostasy in 1903-1914. The total rate of orthodoxization of sectarians was 11,077 people, rate of apostasy in 1905-1914 - 36,400 people. The totals and the dynamics of religious conversion of sectarians indicate that at the beginning of the $20^{\text {th }}$ century the question of the spread of sectarian-type religious communities became acute. In 1916, the Minister of Home Affairs approved a special circular for the governors, in which he focused on the anti-state activities of the illegal and registered sects, the need to eliminate the first ones and to control the second ones, to prosecute the members of the sects for the violation of the Provisional Rules of 1906 about meetings, for public criticism of the socio-economic situation in the country and the political course of the tsarist government $^{33}$.

\section{Conclusion}

Thus, the identification of factors, forms, methods and analysis of the dynamics of religious conversion reveals various integration strategies that the tsarist authorities used in the late imperial period. The forced and economic methods of conversion were applied in the context of the forced integration strategy and their use was determined by the factors of disloyalty (open disloyalty - rebellion or hidden - counteraction to the tsarist policy) and a high degree of cultural affinity between ethnic and religious cultures (in relation to Ukrainians, Belarusians, Lithuanians, Latvians, Estonians), as, for example, in the Western provinces, Privislinsky region and the Baltic States. The use of the forced and economic methods was followed by a high level of orthodoxization and the high rates of apostasy, which reflects the existence of inter-ethnic tensions and the inefficiency of the policies pursued. The educational methods of religious conversion were implemented in the context of the gradual acculturation policy, and their application was determined by the factors of loyalty of ethnic groups and the lack of cultural affinity with indigenous peoples of Siberia and the Far East. In this case, the use of educational methods of religious conversion resulted in the high rates of orthodoxization and the low rates of apostasy, which confirms the efficiency of the integration policy and the absence of interethnic tensions. The recruitment methods can be interpreted as an aspect of management strategies aimed at counteraction to a new phenomenon for imperial Russia - rationalistic sectarianism which was not connected with particular ethnic groups and largely opposed the conservative imperial regime. The natural methods of religious conversion in the context of the existing family and marriage legislation regulating mixed marriages can be considered as an aspect of gradual acculturation strategies which did not result in mass religious transitions. In the case of preservation of the status quo, as in Central Asia, mass religious conversions were not documented. In sum, it appears to be relevant to consider such a phenomenon as religious conversion in the context of national and confessional policies as a criterion of the management strategies used by the tsarist authorities in late imperial Russia.

\section{References}

Ambartsumov I.V. Non-Orthodox Christian Confessions in the System of Russian Statehood (late $20^{\text {th }}$ century - July 1914). Diss. ... kand. ist. nauk. St. Petersburg, 2014, 256 p. (In Russian)

33 Ibid. P. 12. 
Baturin S.P., Baturina T.V. On the Problem of the Confessional Policy in the Russian Empire at the Turn of the $19^{\text {th }}-20^{\text {th }}$ centuries (the Case of Siberia). Vestnik Kemerovskogo gosudarstvennogo universiteta. 2015, vol. 1, iss. 4, pp.7-13. (In Russian)

Bazarianinov V. The Main Factors and the Essence of our Sectarianism. The Experience of Philosophical and Psychological Description of Sectarianism. St. Petersburg, Berezhlivost' Publ., 1904, 46 p. (In Russian)

Bonch-Bruevich V.D. About Religion, Religious Sectarianism and the Church. Moscow, AN SSSR Press, 1959, 410 p. (In Russian)

Chumakova T. Orthodox Priests - Researchers of the Religion of the Peoples of Russia ( $19^{\text {th }}-$ beginning of $20^{\text {th }}$ century). Gosudarstvo, religiia, tserkov'v Rossii i za rubezhom. 2018, vol. 1, pp. 12-32. (In Russian)

Fedorov V.A. Russian Orthodox Church and the State. Synodal period (1700-1917). Moscow, Russkaia panorama Publ., 2003, 480 p. (In Russian)

Fedorov V.A. Russian Orthodox Church and the state. Synodal period (1700-1917). St. Petersburg, St. Petersburg University Press, 2006, 299 p. (In Russian)

Freeze G. L. Confessions in Imperial Russia: Analytical Overview of the Historiography. Bylye gody, 2016, vol. 39, iss. 1, pp. 261-281.

Isaeva V. B. Classical Conceptual Sociological Models of Religious Conversion. Nauchnoe obozrenie. Seriia 2. Gumanitarnye nauki. 2013, vol. 6, pp. 28-36. (In Russian)

Kappeler A. Russia as a Multinational Empire. Emergence. Development. Collapse. Moscow, ProgressTraditsiia Publ., 2000, 342 p. (In Russian)

Karpov V., Lisovskaya E., Barry D. Ethnodoxy: How Popular Ideologies Fuse Religious and Ethnic Identities. Journal for the scientific study of religion. 2012, vol.51, no. 4, pp. 638-655.

Klibanov A. I. Religious Sectarianism in the Past and Present. Moscow, Nauka Publ., 1973, 256 p.

Mironov B. N. Management of the Ethnic Diversity of the Russian Empire. St. Petersburg, Dmitrii Bulanin Publ., 2017, 640 p.

Preobrazhenskii I. V. The Russian Church in Statistical Data from 1840-1841 to 1890-1891. St. Petersburg, Izd-vo E. Arngol'da Publ., 1897, 236 p. (In Russian)

Reisner M. A. State and Believer: a Collection of Articles. St. Petersburg, Obshchestvennaya Pol'za Publ., 1905, 423 p. (In Russian)

Smirnov M. Yu. Sociology of Religion: Dictionary. St. Petersburg, St. Petersburg University Press, 2011, 412 p. (In Russian)

Snow D. A., Zurcher L.A., Ecland-Olson S. Social Networks and Social Movements: a Microstructural Approach to Differential Recruitment. American Sociological Review, 1980, vol.45, iss. 5, pp.787-801.

Stetskevich M.S. Freedom of Conscience: a Handbook. St. Petersburg, St. Petersburg University Press, 2006, 299 p. (In Russian)

Veniamin (Smirnov). About the Conversion to Christianity of the Mezen Samoyeds in 1825-1830. St. Petersburg, Print. E. Fishera, 1851, 78 p. (In Russian)

Vert P. Orthodoxy, Non-Orthodoxy, Heterodoxy: Sketches on the History of Religious Diversity in the Russian Empire. Moscow, Novoe literaturnoe obozrenie Publ., 2012, 210 p. (In Russian)

Zelenin D. K. N. I. Ilminsky and the Education of Indigenous Dwellers: (On the Tenth Anniversary of the Death of N. I. Ilminsky). St. Petersburg, Russkaia Shkola Publ., 1902, 20 p. (In Russian)

Received: March 16, 2019

Accepted: September 9, 2019

Статья поступила в редакцию 16 марта 2019 г.

Рекомендована в печать 9 сентября 2019 г. 